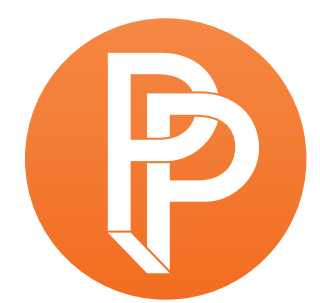

PERFORMANCE

PHILOSOPHY

\title{
PHILOSOPHY AS VERSE-PERFORMANCE: FIVE POEMS AND A FORMALIST PROSPECTUS
}

\author{
CHRISTOPHER NORRIS UNIVERSITY OF CARDIFF
}

\section{Introduction}

The following poems-or verse-essays-are part of an on-going project with two principal and closely related aims. One is revive the fortunes of the broadly philosophical verse-essay, a genre that has been largely neglected over the past two centuries and more since its highpoint in the long literary eighteenth century. The other is to show how this can best be achieved through a formalist poetics involving the deployment of regular rhyme-schemes and likewise regular metrical structures played off against the shifting patterns of speech rhythm. This all runs very much counter to currently approved practice, at least among prominent (mostly academic) arbiters of taste, so I had better explain some of the issues raised by conjoining these two distinctly un-modish attempts.

The main thrust of avant-garde theory over the past few decades has been toward an idea of literary language that locates its resistance to passive or conformist habits of writing or reading primarily in 'the text'. This latter is then conceived-in post-structuralist fashion-as a site of conflicting significations that are defined in terms applying with equal pertinence to poetry or prose (for a fairly representative sampling of work in this vein, see Norris and Machin 1987). That is, it tends to neglect matters of a formal (by which I mean chiefly metrical, rhythmic, prosodic, syntactic, or verse-structural) character so as to engage more intently with the textual and intertextual aspects of poetic discourse. These aspects are more amenable to treatment by thoseespecially philosopher-critics or theorists bred up on a mixture of post-Kantian idealism with post- 
structuralist ideas about language-who see it as their main role to mediate the relationship between poetry and theory. Although these critics do on occasion take note of certain formal features it is usually by way of a brief detour from that other, to them more absorbing and philosophically as well as poetically important business. It strikes me-no doubt as an interested party-that much of the contemporary poetry approved, promoted, anthologised, or encouraged by such criticism can itself fairly be said to suffer from a kindred defect. It often goes beyond the modernist revolt against 'traditional' rhyme and meter-a revolt quite compatible (as in T.S. Eliot) with a high degree of formal inventiveness in both respects-to something more like a cultivated disregard for such elements.

The result, in many cases, is a flattening-out of verse-rhythms through the lack of any metrical counterpoint. One feels that the poem might just as well have been written in prose since there is nothing - or nothing of a properly poetic, i.e., formally constrained but also formally inventive and liberating character-to warrant that generic description. This applies especially to the language poets (or $\mathrm{L}=\mathrm{A}=\mathrm{N}=\mathrm{G}=\mathrm{U}=\mathrm{A}=\mathrm{G}=\mathrm{E}$ poets, as they like to be known) who emerged as a loosely associated movement in the 1970's and occupied ground that, in principle at least, overlapped to a striking extent with the territory I have been trying to stake out here (see especially Andrews and Bernstein 1984; also Bernstein 1992 and 1999; Hejinian 2000; McCaffery 1986 and 2001; Perelman 1996; Silliman 1987; Ward 1993). These poets, Charles Bernstein and Steve McCaffery among them, are highly self-conscious and theoretically aware about the kinds of effect they wish to achieve in creative practice and the kinds of relationship they seek to establish with various poetic and philosophical precursors. In brief: they reject (what they see as) the prevailing subjectivist or expressivist (i.e., neo-Romantic) ethos of much contemporary poetry; go in wholeheartedly for post-structuralist ideas of écriture, the 'revolution of the word', and the limitlessly plural or scriptible text; enthusiastically, and for just those reasons, endorse the Barthesian 'death of the author'; likewise approve the post-structuralist idea of literature's socio-political function as the undoing of bourgeois ideology by deconstructive, semioclastic, or other such textual means; and, again following Barthes, take the naturalisation of the signifier/signified dyad as the basic mechanism by which language colludes in our willing submission to the lures of 'common-sense' thinking. Along with these goes the further belief that the signifiers 'poetry' or 'poem' (not to mention 'poet') have for too long served to promote a notion of literary works as affording privileged access to realms of experience beyond reach of prosaic or rational grasp.

The language-poets advance this case with a passion clearly born of 1960 s political-cultural ferment and transposed, via post-structuralism, to the register of a dissident or radical poetics squarely at odds with the whole bad hegemony of received languages and verse-forms. They alsoas scarcely needs adding-have a deep (and in some ways healthy) suspicion of the first-person subject whose agonies and ecstasies, along with more humdrum emotions, are the fulcrum of most poetry in the mainstream lyric tradition. I won't deny the appeal that such ideas have exerted, and continue to exert, on my own thinking about poetry and theory. Nobody who reads these pieces with an ear and eye to their formal (narrative as well as verse-poetic) aspects would be likely to take them as straightforwardly expressing my own beliefs or indeed the belief-set of any unified, autonomous, or integral first-person self. To that extent I am happy to acknowledge an affinity with 
what the language-poets-or their most influential promoters (usually the same people)-place high on their creative-critical agenda. There is also a genealogical connection in respect of our shared sources in that line of jointly poetic-philosophical writing that goes back through YaleSchool deconstruction to the Jena Romantics. However, in the case of the language poets, there is something too easily or unresistingly achieved about that two-way reciprocal passage between poetry and theory, or the fluency with which these writers modulate from a (nominal) poetry overtly engaged with issues in criticism and theory to a theoretically-angled criticism with claimsnot always very strongly borne out-to constitute poetry in itself. The result is very often a hybrid discourse that fails to match either the creative flair of the best literary theory or the subtlety, range and conceptual resources of a poetry that makes best use of verse techniques for its own distinctive purposes.

This can most plausibly be put down to a deficit of just those formal attributes, such as rhyme and meter, that the language poets frequently denounce as at best mere relics of an antiquated verse tradition and at worst a means of inducing compliance with the norms of bourgeois subjectivity. On the contrary, l'd say: it is just those formal attributes that best, most effectively and durably exemplify poetry's power of resistance to ideological conditioning, whether by the sometimes restrictive effects of first-person (e.g., lyric) individualism or-more to the point here-by the subject's proclaimed dissolution into a multitude of intertextual discourses, codes and conventions. Hence the feeling of linguistic inertness in so much language-poetry and the impression it gives of endlessly announcing but never remotely achieving that revolution of the bourgeois signifying order first envisaged a full half-century ago by the left wing of French structuralist poetics (see for instance Belsey 1980; Kristeva 1984; Young 1981). My verse-essay about Mallarmé is relevant here since it reflects on the various sources of a double and coimplicated movement of thought, one that starts from Mallarmé's diagnosis of a 'crisis' ([1986] (2010) afflicting the high culture of nineteenth-century French classicism and presages the increasing permeability of any generic boundary between poetry and theory, along with the erosion of those formal features that once underwrote (albeit in historically and culturally variable ways) that same distinction. Hence the current anti-formalist bias and, closely allied to that, the prejudice against any poetry that argues a case as distinct from deploying symbolist-approved modes of oblique, evocative, highly metaphoric, non-discursive, analogical, non-consecutive, spatially conceived, and hence maximally non-prosaic language.

However what this attitude gives to poetry in terms of expanded creative-imaginative horizons it promptly takes away in terms of formal resources and capacity to earn its keep as a discourse of reasoned dialogical exchange. The precedents again go a long way back, to the English Romantics at least, although it wasn't until recent times that the idea of radically re-jigging the poetry/prose dichotomy was translated from the realm of generalised precept to poetic practice. Thus Wordsworth ([1800]) 1991) said that the relevant distinction was that between poetry and science, not poetry and prose, while Shelley ([1821] 2001) — with larger territorial aims in view_-said that all major thinkers, discoverers, reformers, scientists and other visionary types should properly be accorded the title of poet. Yet neither of them, even Wordsworth in the prosier parts of Lyrical Ballads, went so far as to draw the inverse corollary of this and remove even those vestiges of 
rhyme and meter that remained of the old (now despised) eighteenth-century 'poetic diction'. That was left to the avatars of twentieth-century modernism and its various, often to begin with academically sponsored but nowadays far more widespread and popular manifestations.

Anti-formalism has had yet further harmful effects. One has been the regrettable division of labour between literary theorists working in self-conceived vanguard movements like post-structuralism or deconstruction and scholar-critics of a more traditional, often philological bent with a primary interest in prosody, metrics, stylistics, structuralist poetics, and genre-theory. (To be sure there are those, like Derek Attridge [1995; 2013], who refuse that division and pursue both projects with notable success.) Meanwhile a good deal of recent poetry-including, non-coincidentally, some of the work most favoured by university-based critics-continues to make a point, even a chief virtue, of its indifference to such presumptively obsolete concerns. Moreover one gets the impression that a main requirement for any poem appearing in some metropolitan literary journals is that it bear no formal marks of being a poem except those of having an unaligned right-hand margin and, very often, a looser grammatical (not to mention thematic and argumentative) structure than one expects of decent prose. It seems to me that this has often gone along with a sizeable and uncompensated loss of those manifold expressive, technical, and (not least) philosophicalreflective resources that are there to be had from rhyme and meter. Anti-formalism and pantextualism can perhaps be seen as flipsides of the same post-Romantic coin, a coupling that I think has a lot to answer for in terms of current poetic and literary-critical practice.

\section{Mallarmé ("A cast of dice....")}

This is a poem about Mallarmé's symbolist poetics with an eye both to its formal innovations in verse-technique-his response to the 'crisis' he perceived as afflicting the classical tradition of French poetry-and to the themes of chance and necessity evoked most suggestively in Un coup de dés. Seeing no future in anything like the traditional rhyme-schemes and metrical forms which had entered that presumptive state of crisis Mallarmé set out to create a poetry of visual, spatial, and (perhaps) ultimately mystic-numerical import that would break with all such precedent. This would bring about the conditions for an epochal advance in the currently stalled unfolding of poetry's formal possibilities and expressive scope. Moreover it would show by such means how certain kinds of highly disciplined poetic creation-or certain modes of highly wrought analogical thought-might demonstrate (as promised in the poem's opening line) that 'a cast of dice will never abolish chance'.

My verse-essay makes its point contre Mallarmé by sticking resolutely to iambic pentameter (the national-cultural equivalent of the French alexandrine so despaired of by Mallarmé) and adopting a rhyme-scheme about as tight, 'classical' and (seemingly) restrictive as could well be conceived. However this is just my point: that if we want a perfect analogy for the paradox that Mallarmé obliquely propounds, that is, the idea of chance (and hence, he implies, of freedom or creative choice) as somehow re-emerging on the far side of necessity then we could hardly do better than 
invoke the instances of poetic rhyme and metre. It is just such formal exigencies that may prompt the poet, even (or especially) when hard pressed, to all sorts of otherwise improbable discovery or invention. In which case, ironically enough, Mallarmés theme in Un coup de dés might be said to find its most striking enactment or exemplification in just those features of the classical tradition whose obsolescence he so fervently proclaimed. At any rate such has been my experience during five years' work in the interstices of poetry-writing and poetics: that it is chiefly through those distinctive verse-attributes-their capacity to dislodge or side-track thought from its habitual linguistic-conceptual grooves-that poetry differs from prose. Or rather, since sweeping claims in that regard are always open to objection by counter-example: it is one chief line of defence for verse-essays like mine that their various turns of argument are carried, invigorated, sharpened, and sometimes sprung upon the rhyme-questing mind by the pressures and challenges of formal constraint.

My dear Degas, poems are not made out of ideas. They're made out of words.

The flesh is sorrowful, alas, and I have read all the books.

The work of pure poetry implies the elocutionary disappearance of the poet, who yields the initiative to words.

Everything in the world exists in order to end up as a book.

I, who am sterile and crepuscular ....

It's still a toss-up (or so Mallarmé

Would have us reckon) even though the dice,

Once cast, must surely come to rest this way

Or that and so relieve us in a trice

Of any thought that randomness might play

Some role beyond that moment of precise

And punctual outcome. Yet the coup de dés,

For him, entailed no such dehiscent slice

Through time's continuum since it jamais 
N'abolira le hasard. If the price

Of this was constellating the array

Of signifiers page-wide (a device

That neutered rhyme and rhythm) then he'd pay

It happily since then we'd profit twice:

By liberating hazard from the sway

Of pitiless Ananke with her vice-

Like grip, and breaking free of that passé

Verse-idiom whose methods to entice

A better class of reader now betray

Their less than noble lineage. Suffice

It here for old-guard classicists to say

His revolution found no room for nice

Prosodic points ('absente de tous bouquets',

These blooms) or fine-tuned strategies to splice

The even measure of a well-made line

With such slight upsets to the steady beat

As might allow the odd alexandrine

To risk its dignity with some discreet

Yet innovative shift to reassign

Stress-patterns over the adjacent feet

And tease the ear. No wonder they decline,

Those prosodists, to contemplate retreat

From principles that let them thus combine

Verse-discipline with strategies that meet

The challenge of Ananke through a fine

And subtly-judged refusal to deplete

Too much of their good stock and so enshrine

Pound's 'make it new!' as just the cry to greet

Each succès de scandale. They intertwine,

These issues, with his master-plan to cheat

Necessity as if on some cloud nine

Where words no sooner land than, tout de suite, 
They self-configure into sibylline

Star-patterns whose receding waves delete

All signals save from those white dwarves that shine

As witness to a universe whose heat-

Death's imaged in their intricate design.

By such means only might his words secrete

The chemistry of that explosante-fixe,

That finite though unbounded cosmos traced

By cancelling the metric troughs and peaks

Of old-style scansion so that their displaced

Vocalic energies, through verse-techniques

More exigent in kind, not go to waste

But reconfigure in a form that seeks

An end to all mere poetising based

On voix humaine. Here language never speaks

In modulated tones and accents graced

By rhyme and metre, or more subtly sneaks

Its entre-nous back in to meet the taste

Of readers unimpressed by such critiques

Since refuge-seekers in that even-paced

And sonorous verse-music that now reeks,

To modernists, of all that once disgraced

The poetry of those-from ancient Greeks

To Hugo and beyond-who interlaced

Art-speech and common parlance. By such tweaks

To that eurhythmic partnership they braced

The vocal nerve to furbish up antiques

Of prosody instead of such mad haste

To free the page of any sound that freaks

The Mallarméans or offends the chaste 
Since ear-decoupled gaze of those intent

On coupling eye and intellect. The main

Idea behind this epochal event

(For such he deemed it) in the verse-domain

Was to display how words might represent

The throw of dice by which Ananke's bane

Might yet be lifted or perchance relent

So far that all the outcomes still remain

In play as if time's arrow underwent

A freeze-frame on its flight to ascertain

Some further outcome, or as if the bent

Of natural necessity might strain

Against itself. Then think to what extent

Effects of rhyme or metre both constrain

And liberate, or how they supplement

The work of thought in ways we can't explain

Except by retrodicting what we meant

To say from what we said. Even so, this train

Of reasoning's sure to throw us off the scent

Since no sign-constellation can ordain

It in the poet's gift to circumvent

The fact that their best efforts to sustain

That saving power might better yet be spent Musing how chance events in rhyme's domain

Are thought's best guide to freedom's continent. 


\section{Giverny}

You'll understand, I'm sure, that I'm chasing the merest sliver of colour. It's my own fault. I want to grasp the intangible. It's terrible how the light runs out. Colour, any colour, lasts a second, sometimes 3 or 4 minutes at most.

Claude Monet

Monet is only an eye, but, good Lord, what an eye!

Paul Cézanne

The critic Florent Fels encountered ... a proud, small old man, who dodged the obstacles in his path uncertainly. Behind the thick lenses of his spectacles, his eyes appeared enormous, like those of an insect searching for the last light.

Ross King, Mad Enchantment: Claude Monet and the Painting of the Water Lilies (2016)

Four minutes at the most, and then they die.

Years since I dreamed I'd get the colours right.

No painted lily graces the mind's eye.

Nice of Cezanne to praise me up, but why

Make something wondrous of an old man's plight?

Four minutes at the most, and then they die.

Ten minutes - more or less - and l'd get by

On memory plus technique as best I might.

No painted lily graces the mind's eye.

Photography is one new trick I try

To conjure up their hues again despite

Four minutes at the most, and then they die.

Time was when those four minutes used to fly

Yet hues would iridesce throughout their flight.

No painted lily graces the mind's eye. 
My dear friend Clemenceau says I'll raise high

The nation's cultural stock, but I take fright:

Four minutes at the most, and then they die.

I'd rather he just spare a passing sigh

For all the hues now lost to vision's blight.

No painted lily graces the mind's eye.

Giverny's my dream-world, yet a far cry

From what that vision once strove to requite:

Four minutes at the most, and then they die.

The critics praise my lilies but apply

Mere words that spell them out in black and white.

No painted lily graces the mind's eye.

The mind's its own place and disclaims what I

Read in each change of hue, however slight:

Four minutes at the most, and then they die.

Then there's the pigments shifting as they dry

Through some strange interzone of day and night.

No painted lily graces the mind's eye.

That eye of mine sees colours go awry

Through cataracts that further cloud my sight.

Four minutes at the most, and then they die.

I scarcely know where water ends and sky

Begins, so it's sheer chaos I invite:

No painted lily graces the mind's eye.

How splendid our precursors who defy

The chaos by their colours clear and bright.

Four minutes at the most, and then they die.

Some days there are when all that fake bonsai

And other Japanese stuff seems just trite.

No painted lily graces the mind's eye.

Georges says he'll fix it so the state will buy

And house my lilies if I just sit tight.

Four minutes at the most, and then they die. 
For what's the point of some cut-price Versailles

If likeness isn't your ambition's height?

No painted lily graces the mind's eye.

A torment to me, that I won't deny,

Yet still I prize those flickerings of the light.

Four minutes at the most, and then they die;

No painted lily graces the mind's eye.

The Reality of the Past: two views

Realism about the past entails that there are numerous true propositions forever in principle unknowable. The effects of a past event may simply dissipate .... To the realist, this is just part of the human condition; the anti-realist feels unknowability in principle to be simply intolerable and prefers to view our evidence for and memory of the past as constitutive of it.

Michael Dummett, The Logical Basis of Metaphysics (1991)

Her only thought: 'This ends it, leaves no shred

Of it behind, our life before

His going. "Nothing's changed by this", he said,

"No part of it, of my and your

Past lives, but think instead

There's all the more,

Even as we look ahead,

To look back on and so restore

To life's bright pattern the unbroken thread

Of how things were." His letter tore

That pattern into pieces as I read.' 
His only thought: 'I hear it, hear the pain

And grief in those last words, though she

Can't cancel out the good things that remain

From back then, all the years that we,

I know, can't live again

Yet still must be

Real-time since they contain

Shared reference-points that she'll agree

Stand firm. But suchlike memory-talk's in vain:

"You've wiped all trace of you-and-me",

She says, "and left no good link in the chain".'

Our only thought: how then to judge this pair

Of shell-shocked young survivors whose

Time-warped perceptions of the past they share

Suggest the other they accuse

Is not the one whom they're

So loth to lose

And who thus has to bear

Whatever sharp reproach they choose

To level, but themselves for taking care

That time befriend them and refuse

All quarter to their partner in despair.

For it's our case that's dress-rehearsed when they

Pursue this vain attempt to show

Either (for her) that nothing could defray

The cost in lives annulled since no

Truth-reckoning lets us say

How much might go

The evanescent way

Of all those years, or else (for so

He thinks of it) that everything should stay

Just as it was in each tableau

Vivant that he'll remember come what may. 
And yet, you know, their differend doesn't quite

Fit our case, us survivors less

Concerned to get the time-conundrum right,

His way or hers, or second-guess

How far that answer might

Ease her distress

Since now there'd come to light

No further memories to oppress

Her past-unburdened soul, or else invite

His glad assent since bound to bless

Remembrance with a direct line of sight.

Let's say the issue's not, for us, the sort

To stir such passions as appear

In his attempt to hold the time-line taut

As truth requires and hers to shear

A link that's lately brought

No souvenir

Unless to stir new thought

Of love as Plato's sundered sphere

With corresponding halves that truly ought

To mate yet never will. Though we're

Stray hemispheres the thing's not quite so fraught.

I mean, we've come out somewhere on the far

Side of those wandering orbits, yet

Perhaps (please help me here) still are,

Years on, not quite prepared to let

The question go or bar

All cause to fret

When crossed ellipses jar

On us who thought we'd paid our debt

To time and truth. Now perturbations mar

The steady state we hoped we'd get

To know as truth timed out each au revoir. 
The mind cannot remain at rest in a mere repertorization of its own recurrent aberrations; it is bound to systematize its own negative self-insight into categories that have at least the appearance of passion, novelty, and difference.

Neat theory, but I doubt it fits our case.

Granted, all signifiers slip and slide,

Yet bygone signifieds still leave their trace.

The gap between might be just empty space

With nothing meant since meaning's open wide.

Neat theory, but I doubt it fits our case.

If breaking up seems easier to face

When past intent affords no future guide,

Those bygone signifieds still leave their trace.

Splendid idea for structuralists to base

Their doctrine on, though here it's misapplied:

Neat theory, but I doubt it fits our case.

Too much gets lost in synchrony's embrace

As it canutes all thought of time and tide

While bygone signifieds still leave their trace.

'If signs make sense,' they say, 'then it's by grace

Of signifiers, not things signified.'

Neat theory, but I doubt it fits our case.

And if they say such doubts are out of place

Since theorists have the whole thing cut-and-dried,

Then bygone signifieds still leave their trace.

Behold those structures crumbling apace.

Time-lapse affirms what synchrony denied.

Neat theory, but I doubt it fits our case. 
Lacanians think the signifier-chase

Goes on and on, but that idea's belied

When bygone signifieds still leave their trace.

For we're the sorts who need to interlace

Times past and present lest they subdivide

And that neat theory retrofits our case

So bygone signifieds can leave no trace.

\section{Doors and Pictures: Wittgenstein}

This poem about the philosopher Ludwig Wittgenstein has its generative source, as regards both topic and rhyme-scheme, in the two words 'say' and 'show'. Wittgenstein's early philosophy-as likewise, in a different way, his later thought-turned crucially on that contrast whether pushed in a linguistic, metaphysical, ethical, or quasi-mystical direction. My poem reflects on the multiple ironies of his life and work, among them the fact that, so far from 'giving philosophy peace' by getting philosophers to drop all those futile since merely abstract disputes, his writings managed to spawn an academic cult and a full-scale industry of Wittgenstein scholarship and exegesis. It is constructed around that resonant pair of rhyme-sounds (say/show), which of course runs the risk of becoming a protracted and rather tedious technical tour de force. However the poem is redeemed, I hope, by conveying a sense of how Wittgenstein deployed his own intellectual and temperamental traits-austere, rigorous, obsessive-compulsive, self-disciplined to the point of self-torment-in some highly creative and idiosyncratic (if philosophically bewilderment-inducing) ways.

It is, I should say, a very far from reverential piece which aims to puncture a few of the pomposities that currently surround his work and have allowed some very dodgy or questionable arguments to gain widespread currency. On the other hand it does try to honour what is impressive-even in an odd way exemplary-about Wittgenstein's facing up to his private demons and managing to keep them from doing more in the way of harm to others. Still one can't help wishing that he'd given them a bit less grief and that the Wittgenstein commentariat hadn't so often emulated the worst aspects of his character in their dealing with others and amongst themselves. 
A picture held us captive. And we could not get outside it, for it lay in our language and language seemed to repeat it to us inexorably.

Ludwig Wittgenstein, Philosophical Investigations

A man will be imprisoned in a room with a door that's unlocked and opens inwards; as long as it does not occur to him to pull rather than push it.

Wittgenstein, Culture and Value

I think I summed up my attitude to philosophy when I said: philosophy ought really to be written only as a poetic composition.

He had this thing about what you could say

And what you couldn't say but only show.

To make that point, he thought, the only way

Was to push 'say' as far as it would go.

With that in mind he'd put up an array

Of reasonings more geometrico,

Along with a meticulous display

Of numbered parts that made it seem as though

The thing was too well-built to go astray.

This would ensure that those chaps in the know,

Bertie and his lot, had their role to play

As dupes in Ludwig's stratagem to blow

A T-shaped hole in everything that they,

Like his Tractarian double, took as so

Self-evident as strictly to convey

No more than syllogistic might bestow

By way of sense or content. Yet dismay

Set in when those same chaps proved far too slow

To take his point, or eager to essay

Some risk-containment exercise that no

Depth-rumblings might disturb. This helped allay

Their nagging sense that he'd contrived to stow

Something in his oblique communiqué

That threatened to upset the status quo

Of language, truth, and logic. Anyway

They picked it up, the cryptic undertow

In this strange work of Russell's protégé,

But made sure it was kept so far below 
Deck in the first translation as to stay

Disarmed of any spanners it might throw

Into the works. For there they'd ricochet

And cause no end of philosophic woe

To Russell and those heralds of the day

When mystics would repay the debt they owe

To logic. Then they'd see fit to obey

Such rational demands as bid them toe

No line where superstition's apt to prey

On trust or faith says reason should forego

Its privilege. Keep saintliness at bay,

His colleagues thought, lest worldly wit lie low

In deference to it and extend the sway

Over weak minds of any holy joe

With some new crack-brained gospel to purvey,

Or any US-style politico

With God on board. That stuff was now passé,

So Russell thought, that Sunday-School tableau

Got up with all the faux-naiveté

By which the firm of Jesus Christ \& Co

Had managed so adroitly to portray

Their potentate as power's most powerful foe.

Yet this ignored Saint Ludwig's dieu caché,

His hidden god (think Pascal, think Godot),

Whose failure to arrive as promised may,

To souls elect, reveal the vapid flow

Of saying's intellectual cabaret

Struck dumb. Thus having nothing à propos

To say-and falling silent-might defray

The cost of all those endless to-and-fro

Discussions spawned, he thought, by the decay

Of what once found expression (think Rousseau)

In sentiments that showing might relay

Once all the saying's done. On this plateau

The tribe of bons sauvages join Mallarmé

In savouring only fragances that blow

From flowers that have their place in no bouquet,

Or hues that vanish in the gaslight glow

Of rainbows shadowed by the grey-on-grey

That passes muster in the Savile Row

Of logic-suited thought. The first rule: pay

No heed to anything we cannot sew, 
Us stitchers-up, to standards checked OK

For sticking to the proper ratio

Of words to thoughts and things lest words outweigh

Truth's currency and thinking undergo

Such figural bewitchments as betray Its old malaise. His message: we should grow

Alert when language 'went on holiday'

Since here it often held in embryo

All the misshapen progeny that lay

Athwart the path to thinking's vrai niveau

Of common speech. Such were those recherché

Linguistic idioms that he thought de trop

Since parasitic on the DNA

Of communal accord, or the escrow

That underwrote our forms of everyday

Folk-usage. This he showed us, modulo

The need for umpteen exegetes to say

Just what it was his words were meant to show,

As witness the shelf-bending dossier

Of monographs and endless de nouveau

Renditions of old themes whose overstay

He'd hoped his Tractatus would long ago

Have laid to rest. Last irony: that they,

His acolytes, should be the ones whom no

Strict rule, like his, against such making hay

With words and concepts could persuade to throw

The habit off despite its threat to fray

The bonds of communal accord and so

Permit such verbal licence (aka

Delinquency) to twist the quid pro quo

That constitutes a true communauté

De langue et vie. His tragedy: to know,

If dimly, that he'd pointed them the way

And sounded the linguistic tallyho

That led his followers to a disarray

Of language-games as likely to kayo

That prospect as the mutants on display

In some linguistic isle where Doc Moreau

Spliced metaphors like genes. And so, malgré

His dearest wish, this anti-Prospero

Saw monstrous life-forms bred out of Roget

By language-games from his own portmanteau. 


\section{Works Cited}

Sources for epigraphs: "Mallarmé ('A cast of dice ... . ')": 'My dear Degas...' from Valéry 1960; 'The flesh is sorrowful, alas!...' from 'Brise Marine' (1887), in Lloyd 1999, 70; 'The work of pure poetry...' from 'Crise de Vers' (1895), in Lloyd 1999, 55; 'Everything in the world exists...' from Mallarmé 1945, 37; 'I who am sterile...' from letter to Henri Kazalis (1865), in Lloyd 1999, 48. "Giverny": all epigraphs from King 2016. "The Reality of the Past: two views": 'Realism about the past...' from Dummet 1991, 7. "Structuralism and Its Discontents": 'The mind cannot remain at rest...' from de Man 1990, 185. "Doors and Pictures: Wittgenstein": 'A picture held us captive...' from Wittgenstein 1954, §115; 'A man can be imprisoned in a room...' from Wittgenstein 1980, 42e; 'I think I summed up my attitude...' from Wittgenstein, 1980, 24e.

Andrews, Bruce, and Charles Bernstein. 1984. The $L=A=N=G=U=A=G=E$ Book. Carbondale: Southern Illinois University Press.

Attridge, Derek. 1995. Poetic Rhythm: An introduction. Cambridge: Cambridge University Press.

-_- 2013. Moving Words: Forms of English poetry. London: Oxford University Press. https://doi.org/10.1093/acprof:oso/9780199681242.001.0001

Belsey, Catherine. 1980. Critical Practice. London: Methuen.

Bernstein, Charles. 1992. A Poetics. Cambridge, MA: Harvard University Press, 1992

. 1999. My Way: Speeches and poems. Chicago, IL: Chicago University Press.

de Man, Paul. 1990. 'Roland Barthes and the Limits of Structuralism.' Yale French Studies 77: 177-90. https://doi.org/10.2307/2930153

Dummett, Michael. 1991. The Logical Basis of Metaphysics. Cambridge, MA: Harvard University Press.

Hejinian, Lyn. 2000. The Language of Inquiry. Berkeley, CA: Berkeley University Press.

King, Ross. 2016. Mad Enchantment: Claude Monet and the Painting of the Water Lilies. London: Bloomsbury.

Kristeva, Julia. 1984. The Revolution in Poetic Language. New York: Columbia University Press.

Lloyd, Rosemary. 1999. Mallarmé: The Poet and his Circle. Ithaca and London: Cornell University Press.

Mallarmé, Stéphane. (1896) 2010. 'Crisis in Poetry.' Translated by Mary Ann Caws. In The Norton Anthology of Theory and Criticism, edited by Vincent Leitch, 841-51. New York: W.W. Norton.

___. 1945. Mallarmé: Oeuvres Completes. Paris: Henri Mondor.

McCaffery, Steve. 1986. North of Intention: Critical writings 1973-86. New York: Roof Book.

2001. Prior to Meaning: The protosemantic and poetics. Evanston, IL: Northwestern University Press.

Norris, Christopher and Richard Machin, eds. 1987. Post-Structuralist Readings of English Poetry. Cambridge: Cambridge University Press.

Perelman, Bob. 1996. The Marginalization of Poetry: Language writing and literary history. Princeton, NJ: Princeton University Press.

Shelley, Percy Bysshe. (1821) 2001. 'A Defence of Poetry'. In Shelley's Poetry and Prose, edited by Donald H. Reiman and Neil Fraistat, 476-90. New York: W.W. Norton.

Silliman, Ron. 1987. The New Sentence. New York: Roof Books.

Valéry, Paul. 1960. Degas, Manet, Morisot. Translated by David Paul. Princeton NJ: Princeton University Press.

Ward, Geoff. 1993. Language Poetry and the American Avant-Garde. Keele: British Association for American Studies.

Wittgenstein, Ludwig. 1954. Philosophical Investigations, edited by G.E.M. Anscombe. Oxford: Blackwell. 
1980. Culture and Value, edited by G.H. von Wright. Oxford: Blackwell.

Wordsworth, William. (1800) 1991. 'Preface'. In Wordsworth and Coleridge: Lyrical Ballads, edited by R.L Brett and A.R. Jones, 286-313. London: Routledge.

Young, Robert, ed. 1981. Untying the Text: A post-structuralist reader. London and New York: Routledge \& Kegan Paul.

\section{Biography}

Christopher Norris is Distinguished Research Professor in Philosophy at the University of Cardiff, Wales. He has written more than thirty books on aspects of philosophy and literary theory, among them (most recently) ReThinking the Cogito: naturalism, reason and the venture of thought; Derrida, Badiou and the Formal Imperative; and Philosophy Outside-In: a critique of academic reason. His volume of verse-essays The Cardinal's Dog and Other Poems appeared in 2013 and two further collections, For the Tempus-Fugitives (Sussex Academic Press) and The Winnowing Fan (Bloomsbury), will be published later this year.

(c) 2017 Christopher Norris

(c) (ㅇ)(2) Except where otherwise noted, this work is licensed under a Creative Commons AttributionC. Non ${ }_{\text {SA }}$ Non Commercial-ShareAlike 4.0 International License. 